\title{
Heaven or Hubris: Reflections on the New ‘New Poverty Agenda'
}

\section{Simon Maxwell*}

A new construction on poverty reduction links the Millennium Development Goals, an international consensus on how to reduce poverty, Poverty Reduction Strategy Papers, a new set of instruments for delivering aid, and, underpinning the others, results-based management. This new construction has undoubted strengths. There are also cross-cutting risks, that targets will oversimplify, citizenship will be neglected, trade-offs and conflicts of interest will be obscured, macro-economic policy will be neglected, social sectors will be emphasised at the expense of growth policies, and commitment to partnership will degrade into a form of covert conditionality. These risks are not immutable. A way forward is proposed, with a list of six principles and a set of Dos and Don'ts.

\author{
Oh! pleasant exercise of hope and joy! \\ For mighty were the auxiliars which then stood \\ Upon our side, we who were strong in poverty reduction! \\ Bliss was it in that dawn to be alive \\ But to be a poverty planner was very heaven! \\ (after William Wordsworth)
}

Wordsworth, above and as amended, has it absolutely right: poverty planning is on a roll. This is because a new construction has been put in place that locks together five elements of new thinking about the subject. The five elements are:

(i) the Millennium Development Goals (MDGs), with poverty reduction at their heart;

(ii) international consensus on how to reduce poverty, best summarised in the World Bank's World Development Report 2000/1: Attacking Poverty;

(iii) a mechanism for operationalising the strategy at country level, in Poverty Reduction Strategy Papers;

\footnotetext{
* Director, Overseas Development Institute and President, Development Studies Association of the UK and Ireland (s.maxwell@odi.org.uk). This article has grown out of lectures for: RAWOO in The Hague; Von Hugel Institute, Cambridge; LSE; the Development Studies Association, Manchester; Royal Holloway College, University of London; and International Training Centre, ILO, Turin. Thanks are due to participants for insights and advice; also to John Roberts for comments. The article draws on earlier papers dealing with different aspects of the new construction (Maxwell and Riddell, 1998; Maxwell and Conway, 2000a, b; Ashley and Maxwell, 2001; Maxwell, 2001b, c; Maxwell and Christiansen, 2002, Maxwell (forthcoming)). I apologise in advance for the degree of self-referencing which this entails. An earlier version of the article appears on the RAWOO website at www.rawoo.nl/main-5l.html and it will be a chapter in R. Black and H. White (eds), Targeting Development (London: Routledge, 2003). Responsibility is the author's. Special thanks are due to David Sunderland.

c) Overseas Development Institute, 2003.

Published by Blackwell Publishing, Oxford OX4 2DQ, UK and 350 Main Street, Malden, MA 02148, USA.
} 
(iv) technologies for delivering aid in support of PRSPs, notably Medium-Term Expenditure Frameworks, Sector-Wide Approaches and Poverty Reduction Support Credits, all associated with budget support rather than project funding; and

(v) underpinning the other four, a commitment to Results-Based Management.

There is no doubt that this construction is superior to previous attempts at housing a new approach to poverty - for example, the initiative on poverty reduction that followed the publication in 1990 of an earlier World Development Report on the subject, described at the time as defining a New Poverty Agenda (Lipton and Maxwell, 1992). That had a strategy, and a degree of operationalisation (for example, through the World Bank's Poverty Handbook and Operational Directive (World Bank, 1992a, b), but lacked the targets, the aid modalities and the emphasis on results-based management.

It is too early to say whether the current and new New Poverty Agenda will deliver the expected results in terms of real poverty reduction for real people in real developing countries. On present trends, as we shall see, many of the MDGs will not be met. We should not, however, be churlish: as Wordsworth remarks, this is a new strategy which

The beauty wore of promise, that which sets

The budding rose above the rose full blown.

True enough, but there are risks associated with this budding rose, and the article is largely about these. The risks lie in the realms of economics, politics and public administration. They include issues to do with equity, consensus-building, partnership, and managing change by simple targets. They are not insignificant risks, but nor are they immutable, and this is the point: by being clear about the risks, we can modify strategies and take action to maximise the probability of success. Not to do so is to fall into the trap of hubris, of pride before a fall.

\section{Poverty reduction: the new construction}

There is much to commend in the new approach to poverty reduction.

\section{The Millennium Development Goals}

The Millennium Development Goals were approved by the General Assembly of the United Nations in 2000. They represent the latest manifestation of the international development targets, agreed (mostly) at UN conferences in the early 1990s, and codified in 1996 by the Development Assistance Committee of the OECD (OECD, 1996). As reproduced in Table 1, there are eight goals and eighteen targets. The core target is to halve by 2015 the proportion of people living on less than \$US1 per day. 


\section{Table 1: The Millennium Development Goals, with associated targets}

\begin{tabular}{|c|c|}
\hline \multicolumn{2}{|r|}{ Goals and Targets } \\
\hline \multicolumn{2}{|c|}{ Goal 1: Eradicate extreme poverty and hunger } \\
\hline Target 1: & $\begin{array}{l}\text { Halve, between } 1990 \text { and } 2015 \text {, the proportion of people whose income is less } \\
\text { than } \$ 1 \text { a day }\end{array}$ \\
\hline Target 2: & Halve, between 1990 and 2015, the proportion of people who suffer from hunger \\
\hline \multicolumn{2}{|c|}{ Goal 2:Achieve universal primary education } \\
\hline Target 3: & $\begin{array}{l}\text { Ensure that, by } 2015 \text {, children everywhere, boys and girls alike, will be able to } \\
\text { complete a full course of primary schooling }\end{array}$ \\
\hline \multicolumn{2}{|c|}{ Goal 3: Promote gender equality and empower women } \\
\hline Target 4: & $\begin{array}{l}\text { Eliminate gender disparity in primary and secondary education, preferably by } \\
2005 \text { and in all levels of education no later than } 2015\end{array}$ \\
\hline \multicolumn{2}{|c|}{ Goal 4: Reduce child mortality } \\
\hline Target 5: & Reduce by two-thirds, between 1990 and 2015, the under-five mortality rate \\
\hline \multicolumn{2}{|c|}{ Goal 5: Improve maternal health } \\
\hline Target 6: & Reduce by three-quarters, between 1990 and 2015 , the maternal mortality ratio \\
\hline \multicolumn{2}{|c|}{ Goal 6: Combat HIV/AIDS, malaria and other diseases } \\
\hline Target 7: & Have halted by 2015 , and begun to reverse, the spread of HIV/AIDS \\
\hline Target 8: & $\begin{array}{l}\text { Have halted by } 2015 \text {, and begun to reverse, the incidence of malaria and other } \\
\text { major diseases }\end{array}$ \\
\hline \multicolumn{2}{|c|}{ Goal 7: Ensure environmental sustainability } \\
\hline Target 9: & $\begin{array}{l}\text { Integrate the principles of sustainable development into country policies and } \\
\text { programmes and reverse the loss of environmental resources }\end{array}$ \\
\hline Target 10: & $\begin{array}{l}\text { Halve, by } 2015 \text {, the proportion of people without sustainable access to safe } \\
\text { drinking water }\end{array}$ \\
\hline Target 11: & $\begin{array}{l}\text { Have achieved by } 2020 \text { a significant improvement in the lives of at least } 100 \\
\text { million slum-dwellers }\end{array}$ \\
\hline \multicolumn{2}{|c|}{ Goal 8: Develop a Global Partnership for Development } \\
\hline Target 12: & $\begin{array}{l}\text { Develop further an open, rule-based, predictable, non-discriminatory trading and } \\
\text { financial system. Includes a commitment to good governance, development, and } \\
\text { poverty reduction - both nationally and internationally }\end{array}$ \\
\hline \multirow[t]{2}{*}{ Target 13: } & Address the special needs of the least developed countries \\
\hline & $\begin{array}{l}\text { Includes: tariff- and quota-free access for LDC exports; enhanced programme of } \\
\text { debt relief for HIPC countries and cancellation of official bilateral debt; and } \\
\text { more generous ODA for countries committed to poverty reduction }\end{array}$ \\
\hline Target 14: & $\begin{array}{l}\text { Address the special needs of landlocked countries and small island developing } \\
\text { states (through Barbados Programme and } 22^{\text {nd }} \text { General Assembly provisions) }\end{array}$ \\
\hline Target 15: & $\begin{array}{l}\text { Deal comprehensively with the debt problems of developing countries through } \\
\text { national and international measures in order to make debt sustainable in the long } \\
\text { term }\end{array}$ \\
\hline Target 16: & $\begin{array}{l}\text { In co-operation with developing countries, develop and implement strategies for } \\
\text { decent and productive work for youth }\end{array}$ \\
\hline Target 17: & $\begin{array}{l}\text { In co-operation with pharmaceutical companies, provide access to affordable, } \\
\text { essential drugs in developing countries }\end{array}$ \\
\hline Target 18: & $\begin{array}{l}\text { In co-operation with the private sector, make available the benefits of new } \\
\text { technologies, especially information and communications }\end{array}$ \\
\hline
\end{tabular}

Source: UNDP website (www.undp.org/mdg/goalsandindicators.html). 
Progress against the targets is uneven. For the key poverty reduction target, the data (Figure 1) show that developing countries taken as a whole are more or less on track to halve the proportion of those in absolute poverty by 2015 , but that this is not true for Europe and Central Asia, the Middle East and North Africa, South Asia, and (most markedly) sub-Saharan Africa. In SSA, the proportion of people living below \$1 a day is rising, not falling. Global success owes a great deal to rapid progress in poverty reduction in East Asia and the Pacific: here, the proportion fell sharply, and the number in absolute poverty declined, during the 1990s, by 192 million people.

\section{Figure 1: Progress towards the Millennium Development Poverty Goals}

Global poverty rates down $20 \%$ since 1990 , but progress is uneven

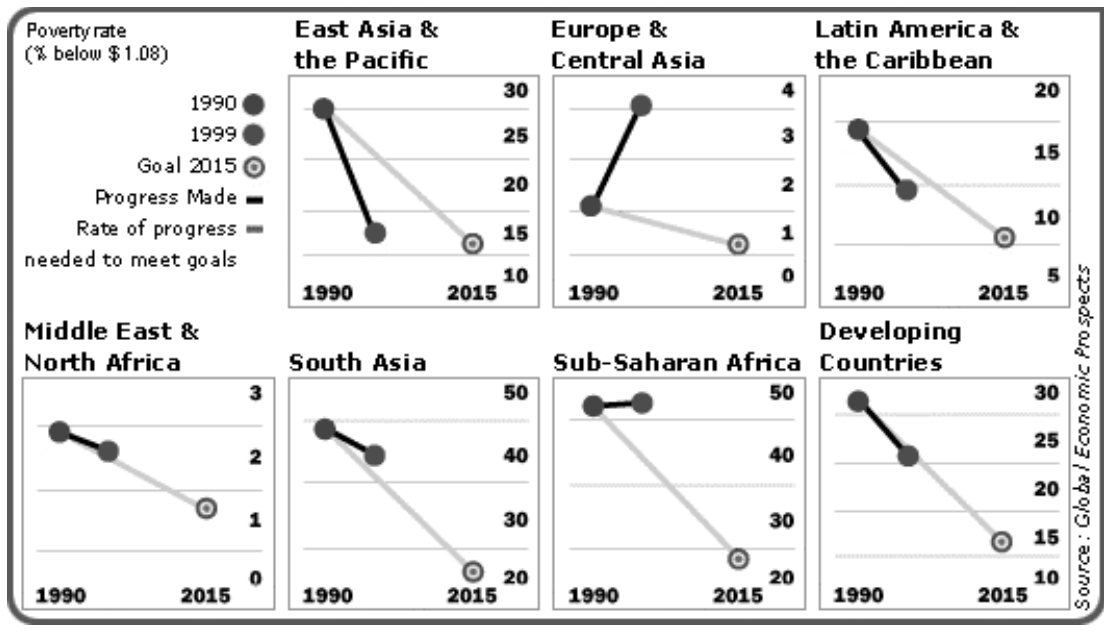

Source: World Bank website (www.developmentgoals.org/Poverty.htm)

We shall come later to some risks associated with using targets to drive policy, but their value in clarifying policy and in providing a political framework deserves to be noted. In particular, the targets have provided political impetus to poverty reduction efforts. As Wordsworth rightly observes:

What temper at the prospect did not wake

To happiness unthought of? The inert

Were roused, and lively natures rapt away!

\section{A strategy to reduce poverty}

The World Development Report 2000/1 laid out a strategy for reducing poverty, resting on three legs: opportunity (meaning growth), empowerment, and security (World Bank, 2000). Other overviews of policy to reduce poverty, for example the DAC Poverty Guidelines, cover similar territory. There are, as we shall see, some rough edges, but the $W D R$ formulation comes close to capturing an international consensus. It has some 
notable innovations, at least for the World Bank. These have been summarised as follows:

- methodological innovation, in the shape of participatory poverty assessments in 60 countries, collectively articulating the Voices of the Poor (see Narayan et al., 2000);

- $\quad$ partly inspired by Voices, but also drawing on an extensive literature, explicit adoption of a multi-dimensional model of poverty, which sets low income alongside access to health and education, vulnerability to shocks, and, importantly, voicelessness and powerlessness;

- emphasis on the value of growth in reducing poverty, as one might expect, but also considerable emphasis on redistribution, admittedly largely for instrumental reasons rather than as an end in itself, as a way of raising the poverty elasticity, but also because more equal societies grow faster;

- predictably again, a commitment to markets and to openness, but strong statements throughout about the dislocations associated with market reform and market processes, the need for strong and prior institutional underpinning of markets, and the 'obligation' (p. 76) to protect losers and those excluded from the benefits;

- empowerment as a major theme, not just participation in a narrow sense, but a focus on making state institutions responsive to poor people (Chap. 6) and on building social institutions (Chap. 7);

- security promoted from being half a leg to a full leg, with a typology of risks, and a review of mitigation, coping and response strategies for natural disasters, economic crises, and many kinds of idiosyncratic risk facing individuals;

- finally, a discussion of international actions around the core themes of opportunity, empowerment and security, which touches on well-worn themes (protectionism in the North, debt relief, more and better aid), but also recognises why countries are nervous about capital market liberalisation and calls for democratisation of global governance institutions (Maxwell, 2001c: 144-5).

It is important to say about the WDR strategy that many of its elements could be found in earlier efforts to synthesise an overall approach to poverty reduction, including earlier WDRs on the subject, in 1980 and 1990, but most notably in the series of UNDP Human Development Reports (HDR) launched in 1990. Thus, the 1990 HDR introduced the multi-dimensional model of poverty in its exploration of 'human development'; it also talked about the need for greater participation and greater equity, and emphasised the importance of social subsidies. The 1997 HDR dealt specifically with poverty, called for greater accountability in government and urged that globalisation be managed to protect and benefit the poor (UNDP, 1997).

That the World Bank should assume part of UNDP's mantle on poverty reduction is, of course, a cause for wonder; but it is also cause for congratulation. WDR 2000/1 marks the closest we have yet come to an international consensus on poverty reduction. The recent DAC Guidelines on Poverty Reduction reflect this on the donor side. In an approach consistent with that of WDR, they adopt a capabilities approach to understanding poverty, incorporating ideas about influence, freedom, status and dignity, 
as well as income and assets; and they cover similar policy areas, including growth, empowerment, social services, and social protection (DAC, 2001: 37ff). Certainly, international discourse has come a long way in the past decade.

\section{Poverty Reduction Strategy Papers}

Poverty Reduction Strategy Papers were introduced in the context of the enhanced HIPC settlement in 1999 (DFID, 2001; Gunter, 2002). Their key features are that they are:

- in principle, country-owned and led;

- based on a participatory process, leading as far as possible to a national consensus;

- accepted by donors on the basis of conditionality on process rather than substance; and

- $\quad$ designed to evolve over time, providing 'road-maps' rather than blueprints for poverty reduction.

In order to qualify for relief under the HIPC Initative, countries must have at least an interim PRSP. Full relief is dependent on having at least a full PRSP. By mid-2002, there were 59 countries involved in the PRSP process. Of these, 14 had completed a full PRSP that had been endorsed by the Boards of the World Bank and the IMF, 6 had completed a full PRSP that had yet to be submitted, 29 had completed an interim PRSP, and 10 were yet to complete an interim PRSP (PRSP Connections, 2002). ${ }^{1}$

\section{MTEFs, SWAPs and PRSCS}

Various 'technologies' have been put in place to help improve the management of public expenditure and aid flows. Governments are encouraged to produce Medium Term Expenditure Frameworks (MTEFs). Donors are encouraged to work together in support of Sector-Wide Approaches (SWAPs). And the World Bank, in particular, is expected to replace structural adjustment lending with new Poverty Reduction Support Credits (PRSCs). Budget support is increasingly replacing project funding.

SWAPs are a particularly important feature of the new apparatus. As described by Foster, the defining characteristic of a SWAP is that

all significant funding for a sector supports a single sector policy and expenditure programme, under Government leadership, adopting common approaches across the sector, and progressing towards relying on Government procedures to disburse and account for all funds. (Foster, 2000: 9)

\section{Results-based management}

Results-based management (RBM) can be characterised as an approach to managing organisations and programmes by focusing on outputs and outcomes rather than inputs

1. The 14 countries with PRSPs endorsed by the Boards were Albania, Bolivia, Burkina Faso, the Gambia, Guinea, Honduras, Mauritania, Mozambique, Nicaragua, Niger, Tanzania, Uganda, Vietnam, and Zambia. 


\section{Table 2: DFID Public Service Agreement: 2003-6: objectives and performance targets}

\section{Objective I: Reduce poverty in Sub-Saharan Africa}

1: Progress towards the MDGs in 16 key countries demonstrated by:

- a sustainable reduction from $48 \%$ in the proportion of people living in poverty across the entire region;

- an increase from $58 \%$ to $72 \%$ in primary school enrolment and an increase from $89 \%$ to $96 \%$ in the ratio of girls to boys enrolled in primary school;

- a reduction from 158 to 139 per 1000 in under-five mortality rates for girls and boys; an increase from $49 \%$ to $67 \%$ in the proportion of births assisted by skilled birth attendants; and a reduction from $16 \%$ in the proportion of 15-24-year-old pregnant women with HIV;

- improved effectiveness of the UK contribution to conflict prevention and management as demonstrated by a reduction in the number of people whose lives are affected by violent conflict and a reduction in potential sources of future conflict, where the UK can make a significant contribution (joint target with FCO and MOD); and

- effective implementation of the G-8 Action Plan for Africa in support of enhanced partnership at the regional and country level.

Objective II: Reduce poverty in Asia

2: Progress towards the MDGs in 4 key countries demonstrated by:

- a sustainable reduction from $15 \%$ to $10 \%$ in the proportion of people living in poverty in East Asia and the Pacific and from $40 \%$ to $32 \%$ in South Asia;

- an increase from $95 \%$ to $100 \%$ in gross primary school enrolment and an increase from $87 \%$ to 94\% in the ratio of girls to boys enrolled in primary school;

- a reduction from 92 to 68 per 1000 live births in under-five mortality rates for girls and boys; and an increase from $39 \%$ to $57 \%$ in the proportion of births assisted by skilled birth attendants; and

- achieving prevalence rates of HIV infection in vulnerable groups to below 5\%; plus a tuberculosis case detection rate above $70 \%$ and cure treatment rate greater than $85 \%$.

Objective III: Reduce poverty in Europe, Central Asia, Latin America, the Caribbean, the Middle East and North Africa

Objective IV: increase the impact of key multilateral agencies in reducing poverty and effective response to conflict and humanitarian crises

3. Improved effectiveness of the international system as demonstrated by:

- a greater impact of European Union external programmes on poverty reduction, including through working for agreement to increase the proportion of EC ODA to low-income countries from $38 \%$ to $70 \%$; and

- ensuring that three-quarters of all eligible HIPC countries committed to poverty reduction receive irrevocable debt relief by 2006 and work with international partners to make progress towards the UN 2015 Millennium Development Goals (joint target with HM Treasury).

4. Secure agreement by 2005 to a significant reduction in trade barriers, leading to improved trading opportunities for the UK and developing countries (joint target with DTI and FCO).

Objective V: Develop evidence-based, innovative approaches to international development

\section{Objective VI: Value for money}

5. Increase from $78 \%$ to $90 \%$ the proportion of DFID's bilateral programme going to low-income countries, plus a sustained increase in the index of DFID's bilateral projects evaluated as successful.

Source: UK Treasury, 2002 (www.hm-treasury.gov.uk/mediastore/otherfiles/psa02_ch11t.pdf). 
and activities: reduction in poverty, say, rather than expenditure on poverty reduction programmes. A good example of its use is in public expenditure management in the UK, where the Treasury negotiates output-oriented Public Service Agreements or contracts with individual ministries. The PSA for the Department for International Development for the period 2002-6 is reproduced by way of illustration in Table 2. It contains five objectives, mostly specifiying the outcomes expected, along with specific targets for poverty reduction or other elements of the MDGs.

It is important to note that RBM is not just used for setting targets. It can also be used to structure rewards, for individuals, teams, organisations, local government departments and the like.

\section{Six risks with the new construction}

The new construction on poverty reduction has undoubted strengths. There are, however, six risks which cut across the various levels of the new construction. We shall come later to remedies.

\section{The risk that targets and performance indicators will oversimplify and distort development efforts}

The use of targets is central to the new construction. They are the main feature, of course, of the Millennium Development Goals; but they also feature strongly in PRSPs, which are about how to reach goals at country level, in SWAPs, which tie public expenditure to targets, and in results-based management.

We know why targets are useful. They clarify objectives; they rally support; and they provide an instrument with which to reform public services. These are valuable benefits. But we also know why targets pose risks: they can encourage a reductionist approach to complex problems, privilege quantitative indicators at the expense of qualitative indicators, distort resource allocation, and undermine professional motivation and responsibility (Maxwell, 1998, forthcoming).

Many examples have been cited in the literature, in both developed and developing countries. Some of the best come from the developed country literature: health targets set centrally as reduction of waiting lists, which encourage doctors to treat less urgent but easy cases and neglect more urgent but more difficult cases (Chapman, 2002); or testing regimes for schools, again set centrally, which distort teaching priorities and provide incentives to teachers to manipulate results (Davies, 2000). In international development, the main debates have been about the reductionist nature of a dollar a day target for poverty reduction (Maxwell, 1998), but also about the difficulty of attribution, when the phenomena with which targets are concerned are subject to many different influences (White, 2002). To take an easy example of the latter. DFID is committed in its Public Service Agreement, reproduced above, to a reduction of poverty in South Asia, from $40 \%$ to $32 \%$ by 2006 . This is a region in which aid is relatively insignificant, accounting for less than $3 \%$ of public expenditure, and in which donors can have relatively little influence on the prospects for growth and poverty reduction. Hubris? Or, a cynic might argue, commitment to a target which is so likely to be achieved that there is little risk of being exposed? 
It might be thought that the right reaction to these problems is to set better targets or manage them differently, but critics argue that the problems lie deeper, in the treatment of professional standards or in the nature of the organisations concerned. Thus, Onora O'Neill rages against the undermining of professional integrity and constructs an argument around issues of trust and accountability. She argues:

Central planning may have failed in the former Soviet Union but it is alive and well in Britain today. The new accountability culture aims at ever more perfect administrative control of institutional and professional life. (O’Neill, 2002)

Chapman sets out the argument about organisations. He argues that public service organisations are complex, adaptive systems which can be expected to respond poorly to centralised targets. Targets will (i) maximise the likelihood of adverse, unintended consequences, (ii) increase administrative overheads, (iii) make institutions more fragile, (iv) demotivate staff throughout the system, and (v) cause disillusion among clients. He concludes that 'the current approach to policy-making and implementation can be expected to fail' (Chapman, 2002: 52, emphasis in original).

\section{The risk that a preoccupation with poverty reduction will detract from the importance of citizenship as an intrinsic component of development}

Poverty reduction is a good objective, particularly if it can be interpreted in the wider human development sense, rather than narrowly in income terms - and if the wider interpretation can be remembered when it comes to monitoring achievement of the relevant Millennium Development Goal. Of course, poverty reduction is not the only MDG. As the full list in Table 1 shows, other targets cover education, health, water, and access to environmental services, all aspects of human capability. Gender equity is a cross-cutting theme.

There are gaps, however. The MDGs are strong on material aspects of deprivation, but not so strong on non-material aspects - which may therefore be neglected in PRSPs and SWAPs. This is about more than the limitations of targets.

Compare the MDGs with the DAC framework on poverty reduction, reproduced in Figure 2 . The boxes on economic, human and protective dimensions broadly correspond to the MDGs (though protection issues are not well handled in the goals). The items covered in the socio-cultural and political boxes, however, are missing from the MDGs. These correspond to the empowerment theme of WDR, and might broadly be interpreted as 'citizenship' (Gaventa et al., 2002). ${ }^{2}$

One interpretation might be that rights, for example, are instrumental to achieving the other aspects, and therefore of a lower priority. In this interpretation, the achievement of income, health or education is what matters, and action to secure achievement is merely the means to the end: citizen action over the right to jobs, health services or schools, for example, or initiatives to make rights justiciable in the constitution or through the legal system.

2. It is notable, however, that rights did not feature in WDR 2000/1. This was a notable gap in WDR's attempt to forge an international consensus, not least since UNDP's HDR took rights as its theme in the same year (Maxwell, 2001c: 146ff). 


\section{Figure 2: Interactive dimensions of poverty and well-being}

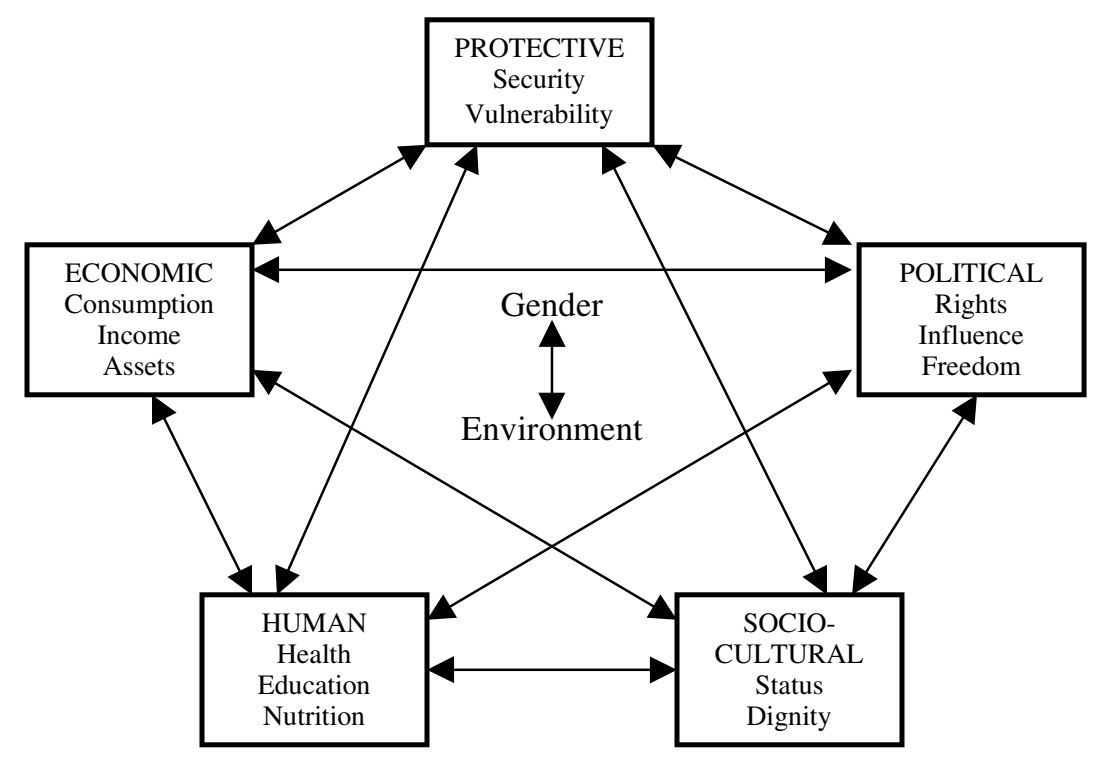

Source: DAC, 2001: 39 .

In fact, few would take this line. As the DAC guidelines make clear, rights, influence, freedom, status and dignity are all components of well-being, part of 'the good life' (Christie and Nash, 1998). They deserve attention in their own right. Moser and Norton describe this as the 'maximum' scenario and make the important point that the achievement of rights is not just about legal structures, but also about social mobilisation. Thus, in a volume entitled 'To Claim Our Rights', they argue that

a growing culture of rights strengthens the degree to which individuals relate to state structures as citizens with rights and responsibilities. In turn, this weakens the extent to which people expect to extract benefits from the state through relations of clientilism and patronage. The citizenship model fosters the capacity for collective action across traditional divisions of class, ethnicity and caste, thereby increasing the capacity of social mobilisation to favour (or at least include) the marginalised. (Moser and Norton, 2001: 39)

This is not simply a theoretical perspective. As Norton and Elson (2002) make clear, there are practical implications for the design of poverty programmes and public budgets.

A related but controversial question is whether equality should also feature as an objective. The treatment in WDR 2000/l is, as noted, largely instrumental: lower inequality is valued because it increases the poverty elasticity (the amount by which a given amount of growth reduces poverty), and also because unequal societies are characterised by violence and insecurity which undermine social capital, disrupt orderly 
economic life and divert resources from productive investment into consumption on security (World Bank, 2000: 52ff). All this is true (Killick, 2002; McKay, 2002; Naschold, 2002; White, 2001), but it can also be argued that lower inequality is a necessary condition for social inclusion, an intrinsic good in its own right. As I have argued elsewhere (Maxwell, 2001b: 335):

Intellectual foundations for this view can be found in the literature on social exclusion (de Haan, 1998), particularly in the French variant which is based on a solidarity paradigm of social inclusion, stressing the importance of social bonds (Silver, 1994). There are connections, too, to the literature on relative deprivation, in which poverty is defined, not in absolute terms, but as a standard of living which is below that 'customary, or at least widely encouraged and/or approved, in the societies to which (people) belong' (Townsend, 1979): a certain degree of equality is implied by this definition.

If these arguments hold, should there not be an international target for inequality? Building on work by Cornia, it has been suggested that a Gini coefficient below 0.45 should be the target (Maxwell, 2001b: 339). On the figures reported in WDR 2000/1, 30 out of 105 countries would miss this target.

\section{The risk that the desire to maximise participation and build a national consensus on poverty reduction will obscure important trade-offs and conflicts of interest}

Although citizenship does not feature as prominently as it might in the MDGs, it is certainly true that participation is a prominent thread of national poverty reduction processes. This begins with Participatory Poverty Assessments (Norton, 2001), but extends to discussion about the content of PRSPs, and to measures which reduce 'capture' by bureaucracies or vested interests, and thereby increase the accountability of government agencies (World Bank, 2000: Chap. 6; Johnson and Start, 2001). There is an increasing wealth of experience with participatory methods, measures to increase accountability, and, more generally, with democratic decentralisation (Johnson, 2001).

This is entirely admirable, but it should not be concluded that conflicts will thereby disappear. A national consensus which obscures the fact that there will be losers as well as winners, probably among the poor as well as between the poor and the non-poor, will do the poor no service.

Many illustrations could be chosen to illustrate this point, but here is one: the contribution of agriculture to poverty reduction. It is a frequent observation that agricultural growth helps reduce poverty, but it does this through many different pathways, with different effects on different groups of poor people, many of them contradictory. Irz et al. (2001) summarise the pathways, in Table 3: agricultural growth can reduce poverty by increasing farm income or employment, by creating jobs or livelihoods in related industries or by means of consumption linkages, lower food prices, or through increased tax revenue being spent on services which benefit the poor. The interests, then, are contradictory: between food suppliers and food buyers; between the producers and consumers of industrial raw materials; and between the urban poor, who favour lower food prices, and the rural poor, who will benefit as net food buyers 
from lower prices, but many of whom will also benefit from greater employment in farm or farm-related industries if prices are high.

\section{Table 3: The benefits of agricultural growth}

\section{Farm economy}

Higher incomes for farmers, including smallholders

More employment on-farm as labour demand rises per hectare, the area cultivated expands, or frequency of cropping increases. Rise in farm wage rates

\section{Rural economy}

More jobs in agriculture and food chain upstream and downstream of farm

More jobs or higher incomes in non-farm economy as farmers and farm labourers spend additional incomes

Increased jobs and incomes in rural economy allow better nutrition, better health and increased investment in education amongst rural population. Lead directly to improved welfare, and indirectly to higher labour productivity

More local tax revenues generated and demand for better infrastructure - roads, power supplies, communications. Leads to second-round effects promoting rural economy

Linkages in production chain generate trust and information, build social capital and facilitate non-farm investment

Reduced prices of food for rural inhabitants who buy in food net

\section{National economy}

Reduced prices of food and raw materials raise real wages of urban poor, reduce wage costs of non-farm sectors

Generation of savings and taxes from farming allows investment in non-farm sector, creating jobs and incomes in other sectors

Earning of foreign exchange allows import of capital goods and essential inputs for non-farm production

Release of farm labour allows production in other sectors

Source: Adapted from Irz et al., 2001.

The implication of this example is that PRSPs and SWAPs, in particular, need to articulate choices and adjudicate between them. In the case of agricultural development, key choices are between crops, farm sizes and degrees of labour intensity, between degrees of liberalisation, and between investment in high and low potential areas (Maxwell, 2001a: 35). No-one should pretend that these choices are not highly contested in most poor countries, and are unlikely to be the subject of a national consensus. Indeed, one of the main conclusions of a recent review of the institutionalisation of PRSPs is that 'politics matters' (Booth et al., 2001). Politics, of course, is partly about the art of achieving change, even when there is no consensus. 


\section{The risk that a focus on public expenditure will distract attention from the importance of macroeconomic policy}

The issue of choices also arises in the context of overall macroeconomic policy, a topic often neglected in countries where the management of public expenditure seems to have become the main instrument of public policy. Yet the fact is that choices made with respect to financial or monetary policy, or trade policy, can have big effects on poor people. Poverty strategies are not good, on the whole, at making these choices clear.

An example is trade policy. It hardly needs to be stated that trade policy is among the most highly contested areas of development policy. On the one hand, trade liberalisation is seen as a rapid route to growth and poverty reduction; on the other hand, it is criticised for being risky at best and often damaging to the poor (Bussolo and Solignac Lecomte, 1999; McCulloch et al., 2001; Morrissey, 2002; Oxfam International, 2002). Very different prescriptions follow. Some are to do with public expenditure: investment in education and infrastructure to facilitate trade, for example, or expenditure on safety nets and other measures to compensate the losers from trade liberalisation. Many others have to do with the overall development stance of the country. The list could include the commitment to state involvement in productive sectors, the regulation of utilities, land reform, labour market issues and core labour standards - all trade-related at some level. As pointed out in Oxfam's recent trade report,

It had been hoped that the new framework for poverty reduction developed by the IMFWorld Bank would help to integrate poverty reduction into all aspects of government policy ... Unfortunately ... experience to date has not been encouraging - especially in the case of trade. No national PRSPs to date have even provided a credible analysis of the potential impact of trade liberalisation on the poor, and none has reviewed existing commitments on trade reform in the light of such an analysis.

In view of the enormous impact of trade liberalisation - for better or for worse - on the livelihoods of the poor, it is essential that its implications are subjected to a proper assessment in advance, rather than a retrospective justification on the basis of preconceived theory. The timing, sequencing, and coverage of liberalisation all need to be carefully reviewed. For example, it may make sense to liberalise imports for a particular agricultural good after the implementation of an investment programme to develop the capacity of small farmers, but not before. Above all, trade liberalisation should be made part of an informed national public debate about poverty-reduction strategies. (Oxfam International, 2002: 246) ${ }^{3}$

3. These findings are broadly consistent with a recent World Bank/IMF review which concluded that 'none of the PRSPs has dealt systematically with past experience of trade reforms, but several PRSPs (including Albania, Honduras, and Mozambique) have included specific measures in support of trade promotion and liberalization. Only in Honduras and Mozambique was there an attempt to clarify the link between these reforms, and growth and poverty reduction' (IDA and IMF, 2002: para 43). 


\section{The risk that focusing on sectors where SWAPs work well will over- emphasise social sectors at the expense of growth policies and cross- cutting themes like rural development}

Sector-Wide Approaches are proving to be a powerful instrument for improving the management of aid, delivering co-ordinated donor support through the budget and in pursuit of agreed targets. This is certainly a big improvement over a world where donors cherry-pick individual projects, often outside the budget. There are, however, problems in applying the approach to cross-cutting sectors like rural development, say, or nutrition.

Early experience shows that there are conditions under which SWAPs are likely to work, and others which will be more difficult. Foster (2000: 10) lists the requirements as:

- public expenditure is a major feature of the sector;

- the donor contribution is substantial;

- there is a basic agreement on strategy between government and donors;

- the macro budget environment is supportive;

- institutional relationships are manageable;

- the incentives are such as to garner support in sectoral ministries.

Several of these present problems from the point of view of cross-cutting issues. For example, the first requirement has been cited as the reason why SWAPs work well in sectors like health, education, and roads, where the private sector is relatively small, and where expenditure (rather than, say, pricing policy) is the main determinant of outcomes, and not so well in agriculture, where public expenditure is less important, and policy more important (Foster et al., 2001). Nutrition is another sector where public expenditure certainly has a role to play, but where private expenditure (not least on food) is also important, and where policy decisions (for example, on exchange rates or food safety regulation) can have a major impact.

The fifth requirement, about institutional relationships, has been interpreted to mean that SWAPs work well when an identifiable ministry controls a sector, and not so well otherwise. Foster observes that

sector programmes have worked most effectively where they are defined in terms of the area of budget responsibility of a single sector ministry; programmes in education or health have proved more manageable than sector programmes for cross-cutting themes such as the environment. (Foster, 2000: 10)

This would appear to place a multi-sectoral area at some disadvantage.

The sixth requirement, about incentives, may also be relevant to cross-cutting programmes in some circumstances, especially if large reallocations of funds between programmes (and probably between ministries) are involved. The argument is that public officials will only respond well to SWAPs if they are likely to receive increased funding as a result. Winners will support SWAPs; losers will not. 


\section{The risk that commitment to partnership will degrade into a form of covert conditionality}

'Partnership' is another term that runs through the new construction of poverty. It features centrally in the MDGs and is especially important in the discussion about new aid modalities, for example the Comprehensive Development Framework (Wolfensohn, 1999). Key concepts include: shared ideals, trust, transparency, dialogue, and frequent review. The main fault lines in the debate are about how to achieve genuine, reciprocal accountability, and about the extent to which partnership arrangements should be contractual.

On reciprocal accountability, the problem arises from the inequality built into the relationship between a rich and powerful donor and a poorer, less powerful 'beneficiary'. Donor countries have expectations of their developing country partners, such as good governance, and also control the real flow of resources and concessions, for example aid and trade access. In these circumstances, the relationship is most easily understood as one of 'asymmetric accountability' (Maxwell and Riddell, 1998).

One way to counter this is for the partnership to be contractual, with obligations written down and procedures put in place for independent review. A prototype example is the Cotonou Convention between the European Union and 77 countries of the African, Caribbean and Pacific (ACP) group. This specifies standards with respect to human rights, democratic principles, the rule of law, and corruption. Joint institutions of the ACP, in particular the joint Council of Ministers, monitor the partnership and adjudicate disputes. The system has yet to be tested fully, and at this stage applies more to the developing countries than to the EU. But it would be perfectly possible to imagine future Conventions specifying standards to which the EU should adhere (aid flows, for example, or trade access).

An alternative, though weaker, approach is that of peer review. The approach has long been used in the Development Assistance Committee of the OECD, whereby donor countries monitor each other's performance. It is now being taken up by developing countries, for example in the context of the New Partnership for African Development (NePAD, 2001). An innovation proposed by NePAD is that peer review be reciprocal, involving review of donor policies by African governments. This is certainly a step on the road to full reciprocal accountability.

The DAC guidelines on poverty reduction emphasise the importance of partnership, and give some indication as to what might be required on the donor side. They stress that 'working in partnership means giving serious attention to assessing agency performance in measuring up to agreed responsibilities and obligations' and suggest the indicative criteria set out in Table 4. The use of the word 'commitment' in respect of resource transfers suggests that the DAC has moved some way from an earlier and more cautious position, in which the term 'compact' was preferred to the idea of 'contract' (OECD, 1996). 


\section{Table 4: Assessing development agency efforts at policy reduction}

Working in partnership means giving serious attention to assessing agency performance in measuring up to agreed responsbilities and obligations. The following indicative criteria could be useful in this regard:

- Is the development agency's country strategy based on the partner country's own assessment and strategy for addressing poverty?

- To what extent does the agency's country strategy address the multidimentional aspects of poverty?

- To what extent have the agency's co-operation activities been carried out jointly or in co-ordination with other bilateral and multilateral development agencies (for example missions, appraisals, data collection, analyses, etc.)?

- Allowing for agency constraints, to what extent have agency administrative and financial requirements been adjusted to, or harmonised with, the partner country's existing procedures or with those of other external partners, where these procedures are deemed appropriate?

- To what extent has the agency implemented its support in a manner which respects and fosters partner country ownership?

- Has the agency supported and strengthened country-led planning, implementation and co-ordination processes?

- Has the agency helped to facilitate civil society's participation (at local, national, and international level) in debating and deciding the contents of the country's poverty reduction strategy in ways that respect government efforts and concerns?

- Has there been a clear, serious commitment of resources to poverty reduction?

- Has a commitment been made to provide predictable resources over a medium-term planning timeframe?

- Has sufficient care been taken to avoid duplication of effort and to build on complementarities across the external development community?

- Have efforts been made to improve policy coherence within the agency and, more broadly, across the full range of DAC member government ministries and departments, and has progress been achieved?

Source: DAC, 2001: 59.

\section{Ways forward}

We have listed problems, but the intention is not to undermine new approaches. Remember, these are risks, and the way to deal with risks is to recognise them in advance and take appropriate action.

What, then, would be appropriate? There are two alternative approaches, and again Wordsworth had his finger on the button, identifying both a top-down and a bottom-up approach:

either this (top-down)

The playfellows of fancy, who had made All powers of swiftness, subtilty and strength Their ministers - who in lordly wise had stirred Among the grandest objects of the sense, And dealt with whatosever they found there 
As if they had within some lurking right

To wield it;

or this (bottom-up)

They, too, who, of gentle mood,

Had watched all gentle motions, and to these

Had fitted their own thoughts, schemers more wild,

And in the region of their peaceful selves;

A bottom-up approach seems more consonant with current approaches, which stress developing country ownership and process rather than the wielding of power by the 'Lords of Poverty' (Hancock, 1989) and other outside agencies. What might it mean in practice? There are six principles:

(i) Practise subsidiarity. Donors need to be flexible in encouraging countries to set their own targets and design their own strategies, and central governments need to be equally flexible in dealing with local government and professional bodies. Conditionality on process rather than substance needs to be maintained, in the implementation of programmes as well as in setting targets. ${ }^{4}$ This might mean that targets and programmes set locally bear little relation to the MDGs. So be it.

(ii) Focus on the essentials. The last thing PRSPs should be is documents which touch every base, cover every point, mention every sector, design every programme, set every target, and establish every monitoring procedure. A PRSP should help to establish the big picture and adjudicate on the key choices: state or market, institutions before liberalisation, open economy or closed economy. If the big picture is right, then the sectors will begin to take care of themselves.

(iii) Do not forget the 'difficult' sectors and the cross-cutting issues. Remember that the current technologies of aid delivery favour social sectors because these meet the criteria for successful SWAPs. Yet it is important to include sectors like agriculture which do not meet the criteria, and to tackle issues like rural development which are not usually ministry-led sectors at all.

(iv) Recognise the political nature of poverty reduction. Ownership is important, and so is participation. Empowerment is rightly a major theme of the new approach. However, it would be naive to expect a national consensus on poverty reduction policy: the poor are not a homogeneous group, and will not have identical interests.

(v) Build partnerships based on reciprocal accountability. It is important not to forget that partnership is a two-sided coin. Mutual accountability is a cardinal principle.

(vi) Follow a process approach. Interim and even full PRSPs are only the first step. They are being revised at regular intervals. Donors should not ask too much of PRSPs, especially in the early stages. Partnerships take time to build.

4. Chapman (2002) develops the idea of a 'soft systems' approach to managing public sector organisations, building on the theory of learning organisations. See Maxwell (forthcoming) for more detail and a discussion of the application to results-based management. 
These principles are not theoretical. They can be summarised operationally, for donors, as a list of Dos and Don'ts.

\title{
Table 5: Dos and don'ts of implementation
}

\begin{tabular}{|c|c|}
\hline Dos & Don'ts \\
\hline Reinforce government leadership & Impose rigid conditionalities \\
\hline Encourage a broad-based debate & Assume consensus is possible \\
\hline $\begin{array}{l}\text { Expect a strategic vision which identifies and } \\
\text { adjudicates between key macroeconomic and } \\
\text { public expenditure choices }\end{array}$ & Expect to agree with all the vision \\
\hline $\begin{array}{l}\text { Ensure that productive sectors and cross- } \\
\text { cutting issues are properly dealt with }\end{array}$ & $\begin{array}{l}\text { Focus only on social sectors amenable to } \\
\text { SWAPs }\end{array}$ \\
\hline Encourage subsidiarity in setting targets & Insist on international targets \\
\hline $\begin{array}{l}\text { Encourage process approaches to managing } \\
\text { public services }\end{array}$ & $\begin{array}{l}\text { Suggest using results-based management in a } \\
\text { narrow way }\end{array}$ \\
\hline Disburse quickly & Insist on the perfect plan before starting \\
\hline Revise frequently & Make unrealistic demands for data \\
\hline Build two-way accountability & Set performance standards for one side only \\
\hline
\end{tabular}

Source: Adapted from Maxwell and Conway (2000a: 21)

If we implement these principles, then there is no reason to worry about hubris. We can be, indeed, in very heaven:

\author{
Not in Utopia, subterranean fields \\ Or some secreted island, Heaven knows where! \\ But in the very world, which is the world \\ Of all of us, - the place where in the end \\ We find our happiness, or not at all!
}

\section{References}

Ashley, C. and Maxwell, S. (2001) 'Rethinking Rural Development', Development Policy Review 19 (4): 395-425.

Booth, D. et al. (2001) 'PRSP Institutionalisation Study: Final Report'. Report submitted to the Strategic Partnership with Africa. London: ODI.

Bussolo, M. and Solignac Lecomte, H.-B. (1999) Trade Liberalisation and Poverty. ODI Poverty Briefing 6. London: ODI, December.

Chapman, J. (2002) System Failure: Why Governments Must Learn to Think Differently. London: Demos.

Christie, I. and Nash, L. (1998) 'The Good Life', Demos Collection 14. London: Demos.

DAC (2001) The DAC Guidelines on Poverty Reduction. Paris: OECD.

5. Wordsworth, of course, was not a poverty planner in the modern sense. All the quotations come from his poem of 1809, 'The French Revolution as it appeared to enthusiasts at its commencement'. The full text can be found at: www.bartleby.com/145/ww285.html 
Davies, N. (2000) 'Fiddling the Figures to Get the Right Results', The Guardian. 11 July.

de Haan, A. (1998) 'Social Exclusion: An Alternative Concept for the Study of Deprivation', IDS Bulletin 29 (1): 10-29.

DFID (2001) Poverty Reduction Strategies. DFID Background Briefing ( $2^{\text {nd }}$ edn). London: DFID, June.

Foster, M. (2000) New Approaches to Development Co-operation: What Can We Learn from Experience with Implementing Sector Wide Approaches? ODI Working Paper No. 140. London: ODI.

Foster, M., Brown, A. and Naschold, F. (2001) 'Sector Programme Approaches: Will They Work in Agriculture?', Development Policy Review 19 (3): 321-38.

Gaventa, J., Shankland, A. and Howard, J. (eds) (2002) 'Making Rights Real: Exploring Citizenship, Participation and Accountability', IDS Bulletin 33 (2).

Gunter, B. (2002) 'What's Wrong with the HIPC Initiative and What's Next?', Development Policy Review 20 (1): 5-24.

Hancock, G. (1989) Lords of Poverty. London: Macmillan.

IDA and IMF (2002) 'Review of the Poverty Reduction Strategy Paper (PRSP) Approach: Main Findings'. (Available at www.worldbank.org/poverty/strategies/ review/findings.pdf).

Irz, X, Lin, L., Thirtle, C. and Wiggins, S. (2001) 'Agricultural Productivity Growth and Poverty Alleviation', Development Policy Review 19 (4): 449-66.

Johnson, C. (2001) 'Local Democracy, Democratic Decentralisation and Rural Development: Theories, Challenges, and Options for Policy', Development Policy Review 19 (4): 521-32.

Johnson, C. and Start, D. (2001) Rights, Claims and Capture: Understanding the Politics of Pro-poor Policy. ODI Working Paper No. 145. London: ODI.

Killick, T. (2002) Responding to Inequality. DFID Inequality Briefing Paper No. 3. London: DFID, March.

Lipton, M. and Maxwell, S. (1992) The New Poverty Agenda: An Overview. IDS Discussion Paper No. 306. Brighton: Institute of Development Studies at the University of Sussex, August.

Maxwell, S. (1998) 'International Targets for Poverty Reduction and Food Security: A Mildly Sceptical but Resolutely Pragmatic View with a Call for Greater Subsidiarity', Canadian Journal of Development Studies XIX, Special Issue.

Maxwell, S. (2001a) 'Agricultural Issues in Food Security', in S. Devereux and S. Maxwell (eds), Food Security in Sub-Saharan Africa. London: ITDG Publishing.

Maxwell, S. (2001b) 'Innovative and Important, Yes, but also Instrumental and Incomplete: The Treatment of Redistribution in the "New Poverty Agenda", Journal of International Development 13 (3): 331-41.

Maxwell, S. (2001c) 'WDR 2000: Is There a New "New Poverty Agenda"?', Development Policy Review 19 (1): 143-9.

Maxwell, S. (forthcoming) 'Lost in Translation? Implementation Constraints to ResultsBased Management', in UNDP/DFID, Enhancing Development Effectiveness: A New Focus on Managing for Results. New York: Earthscan (provisional).

Maxwell, S. and Christiansen, K. (2002) 'Negotiation as a Simultaneous Equation: Building a New Partnership with Africa', International Affairs 78 (3): 477-91. 
Maxwell, S. and Conway, T. (2000a) New Approaches to Planning. World Bank Operations Evaluation Department (OED) Working Paper Series No. 14. Washington, DC: World Bank, Summer.

Maxwell, S. and Conway, T. (2000b) Perspectives on Partnership. World Bank Operations Evaluation Department (OED) Working Paper Series No. 6. Washington, DC: World Bank, Summer.

Maxwell, S, and Riddell, R. (1998) 'Conditionality or Contract? Perspectives on Partnership for Development', Journal of International Development 10 (2): 25768.

McCulloch, N. et al. (2001) Trade Liberalisation and Poverty: A Handbook. London: Centre for Economic Policy Research.

McKay, A. (2002) Defining and Measuring Inequality. Inequality Briefing Paper No. 1. London: DFID, March.

Morrissey, O. (ed.) 'Policy Symposium: WTO, Doha and Developing Countries', Development Policy Review 20 (1): 41-102.

Moser, C. and Norton, A. (2001) To Claim Our Rights: Livelihood Security, Human Rights and Sustainable Development. London: ODI.

Narayan, D. et al. (2000) Voices of the Poor: Can Anyone Hear Us?. New York: Oxford University Press for the World Bank.

Naschold, F. (2002) Why Inequality Matters for Poverty. Inequality Briefing Paper No. 2. London: DFID, March.

NePAD (2001) 'Policy Document' (English version). (October) (Available at www.nepad.org/ Documents/AA0010101.pdf).

Norton, A. (2001) A Rough Guide to PPAs: Participatory Poverty Assessment - An Introduction to Theory and Practice. London: ODI.

Norton, A. and Elson, D. (2002) What's Behind the Budget?: Politics, Rights and Accountability in the Budget Process. London: ODI.

OECD (1996) Shaping the 21 $1^{\text {st }}$ Century: The Contribution of Development Cooperation. Paris: OECD.

O'Neill, Onora (2002) 'A Question of Trust'. Reith Lectures No. 3. (Available at www.bbc.co. uk/radio4/reith2002/lecture3_text.shtml).

Oxfam International (2002) Rigged Rules and Double Standards: Trade, Globalisation, and the Fight Against Poverty. Oxford: Oxfam.

PRSP Connections (2002) PRSP Connections: Monitoring and Synthesis Project. Issue 5. London: ODI, May.

Silver, H. (1994) Social Exclusion and Social Solidarity: Three Paradigms. IILS Discussion Paper 69. Geneva: IILS.

Townsend, P. (1979) Poverty in the UK. Harmondsworth: Penguin.

UK Treasury (2002) 'Public Service Agreement for the Department for International Development', in Comprehensive Spending Review 2002-2006. London: HM Treasury.

UNDP (1997) Human Development Report. New York: Oxford University Press for UNDP.

White, H. (2001) 'National and International Redistribution as Tools for Poverty Reduction', Journal of International Development 13 (3): 343-52.

White, H. (2002) 'A Drop in the Ocean? The International Development Targets as a Basis for Performance Measurement', Appendix 2 in National Audit Office, DFID: 
Performance Management - Helping to Reduce World Poverty. Report by the Controller and Auditor General. London: National Audit Office, April.

Wolfensohn, J. (1999) 'A proposal for a Comprehensive Development Framework' (discussion draft). Memo to the Board, management and staff of the World Bank Group. Washington, DC: World Bank, 21 January.

World Bank (1992a) 'Poverty Handbook'. Discussion draft. Washington, DC: World Bank.

World Bank (1992b) Poverty Reduction Operational Directive. Washington, DC: World Bank.

World Bank (2000) World Development Report 2000/2001: Attacking Poverty. New York: Oxford University Press for the World Bank. 